\title{
The snf1 Gene of Ustilago maydis Acts as a Dual Regulator of Cell Wall Degrading Enzymes
}

\author{
Marina Nadal, Maria D. Garcia-Pedrajas, and Scott E. Gold
}

First and third authors: Department of Plant Pathology, University of Georgia, Athens 30602-7274; and second author: Instituto de Hortofruticultura Subtropical y Mediterránea "La Mayora”, Universidad de Málaga-Consejo Superior de Investigaciones Científicas (IHSM-UMA-CSIC), Estación Experimental "La Mayora”, 29760 Algarrobo-Costa, Málaga, Spain.

Current address of M. Nadal: Department of Plant Molecular Biology, University of Lausanne, Biophore Building, CH-1015 Lausanne, Switzerland.

Accepted for publication 17 August 2010.

\begin{abstract}
Nadal, M., Garcia-Pedrajas, M. D., and Gold, S. E. 2010. The snfl gene of Ustilago maydis acts as a dual regulator of cell wall degrading enzymes. Phytopathology 100:1364-1372.

Many fungal plant pathogens are known to produce extracellular enzymes that degrade cell wall elements required for host penetration and infection. Due to gene redundancy, single gene deletions generally do not address the importance of these enzymes in pathogenicity. Cell wall degrading enzymes (CWDEs) in fungi are often subject to carbon catabolite repression at the transcriptional level such that, when glucose is available, CWDE-encoding genes, along with many other genes, are repressed. In Saccharomyces cerevisiae, one of the main players controlling this process is $S N F 1$, which encodes a protein kinase. In this yeast, $\operatorname{Snflp}$ is required to release glucose repression when this sugar is

depleted from the growth medium. We have employed a reverse genetic approach to explore the role of the $S N F 1$ ortholog as a potential regulator of CWDE gene expression in Ustilago maydis. We identified $U$. maydis snfl and deleted it from the fungal genome. Consistent with our hypothesis, the relative expression of an endoglucanase and a pectinase was higher in the wild type than in the $\Delta s n f 1$ mutant strain when glucose was depleted from the growth medium. However, when cells were grown in derepressive conditions, the relative expression of two xylanase genes was unexpectedly higher in the $\Delta s n f 1$ strain than in the wild type, indicating that, in this case, snfl negatively regulated the expression of these genes. Additionally, we found that, contrary to several other fungal species, U. maydis Snf1 was not required for utilization of alternative carbon sources. Also, unlike in ascomycete plant pathogens, deletion of snfl did not profoundly affect virulence in U. maydis.
\end{abstract}

Many plant pathogens actively force entrance into their host by employing mechanical or enzymatic methods or a combination of both. Many pathogenic fungi produce a specialized organ termed an appressorium able to generate enough turgor pressure to pierce the plant surface $(9,15)$. The melanized appressorium of the rice blast fungus Magnaporthe oryzae can reach turgor pressures of 5.8 MPa (10). In addition to producing an appressorium, the corn leaf blight fungus Cochliobolus carbonum secretes a cocktail of cell wall degrading enzymes (CWDEs) that depolymerizes the different constituents of the plant cell wall, allowing the fungus to penetrate and spread within the host (45). The importance of CWDEs as virulence factors in fungi has only recently begun to be understood. Several CWDEs, including pectinases and endoxylanases, not only might aid pathogens during colonization of their hosts but the resulting enzymatic products may also function as elicitors to trigger plant defense mechanisms $(3,25)$. Due to gene and enzymatic activity redundancy, reverse genetic approaches relying on single or even multiple gene deletions have not effectively addressed the importance of these enzymes in pathogenicity $(17,35,46)$.

In the basidiomycete Ustilago maydis, causal agent of corn smut, when two compatible haploid sporidia mate on the plant surface, the resulting dikaryotic infective hypha produces a poorly differentiated appressorium at the site of entry (38). Within the host, the fungus spreads initially intracellularly by penetrating the host cell wall and invaginating the plasma membrane (39). The

Corresponding author: S. E. Gold; E-mail address: sgold@uga.edu

doi:10.1094/PHYTO-01-10-0011

(c) 2010 The American Phytopathological Society occurrence of deformed rupture sites between plant cells suggests that some mechanical mechanism might be involved in the fungal ramification inside the plant. However, because there is no welldifferentiated melanized appressorium, enzymatic digestion of plant cell wall components as a requisite for penetration is implied.

Using confocal microscopy, Doehlemann et al. (13) were able to demonstrate that, in U. maydis in later stages of gall formation, the fungal hyphae form aggregates that fill enlarged apoplastic cavities that result from degradation of the middle lamella between tumor cells. The authors also analyzed the pattern of expression of CWDE gene induction during pathogenic development and concluded that degradation of hemicellulose and cellulose may be critical for tissue colonization in all stages of disease development; however, pectin degradation might be required only for cavity development. Although this information points toward a pathogenic $U$. maydis employing an enzymatic approach, reverse genetics has not been successful in addressing the question, primarily due to gene redundancy but also because cell wall degradation might require coordinated activities of several CWDE classes rather than single enzyme types (13).

An interesting aspect of the function of CWDEs in fungi is that they are usually under transcriptional glucose repression (33). Glucose repression is a widespread mechanism exploited by organisms for which glucose is the preferred carbon source, such as that exhibited by baker's yeast, Saccharomyces cerevisiae (16). In $S$. cerevisiae, sucrose-nonfermenting ( $\mathrm{Snf} 1)$ serine-threonine protein kinase is required to release glucose transcriptional repression when this sugar is depleted $(5,20)$. Snflp forms a complex with the activating $\gamma$-subunit, $\operatorname{Snf} 4 \mathrm{p}(7,34)$, and one of the three $\beta$-scaffolding subunits: Sip1p, Sip2p, or Gal83p $(20,44$, 
47). High levels of glucose inhibit the interaction between Snf1p and Snf4p (42). When glucose levels are low, Snf4p binds to the Snflp regulatory domain, preventing the autoinhibition that this domain exerts on the Snflp kinase domain. The $\beta$-scaffolding subunits interact with the Snf1p through a KIS domain and with Snf4p through its C-terminal ASC domain $(24,48)$. Each $\beta$ scaffolding subunit is thought to confer specificity by mediating the binding of the Snf1 complex to a particular target or targets (44). One of the principal targets of the Snf1p catalytic $\alpha$-subunit is the DNA-binding transcriptional repressor Mig1 (42). Phosphorylation of Mig1p by the Snf1 complex promotes its export to the cytoplasm, allowing transcription of the otherwise glucoserepressed genes $(1,11,37)$.

In the human fungal pathogen Cryptococcus neoformans, the SNF1 ortholog is required for alternative carbon source utilization, melanin production, and virulence; whereas, in the phytopathogenic ascomycete fungi, Fusarium oxysporum and Cochliobolus carbonum, disruption of the corresponding SNF1 orthologs led to a reduction in the expression of several CWDE genes, accompanied by a major decrease in virulence $(32,41)$. In this work, we explored the SNF1 ortholog in the basidiomycete fungus $U$. maydis in connection to its role in CWDE expression and virulence. We present data indicating that, in $U$. maydis, Snf1 is not necessary for releasing glucose repression of some CWDE genes or to metabolize alternative carbon sources. Most importantly, deletion of snfl, unlike in plant-pathogenic species studied to date, did not profoundly affect virulence in $U$. maydis.

\section{MATERIALS AND METHODS}

Strains, media, and growth conditions. $U$. maydis strains used in this study are listed in Table 1. Fungal cultures were grown on potato dextrose agar (PDA) or in potato dextrose broth (PDB) (Difco Laboratories, Franklin Lakes, NJ). Nitrate minimal medium (MM) (23) amended with $1 \%$ (wt/vol) of either oat spelt xylan, citrus pectin, sucrose, glucose, or arabinose (SigmaAldrich, St. Louis) was employed for growth assays and gene expression experiments. $U$. maydis cultures for protoplast production were grown in YEPS (1\% yeast extract, $2 \%$ bacto-peptone, and $2 \%$ sucrose). U. maydis transformants were selected on YEPS medium amended with $1 \mathrm{M}$ sorbitol (YEPS-S) and carboxin at $3 \mu \mathrm{g} / \mathrm{ml}$ (Gustafson, Inc., Plano, TX). Cultures were grown at $30^{\circ} \mathrm{C}$ and, for liquid cultures, agitation in a rotary shaker was kept at $250 \mathrm{rpm}$. Escherichia coli DH5 $\alpha$ cells were used for transformation during deletion construct assembly. Luria-Bertani (LB) medium containing ampicillin at $50 \mu \mathrm{g} / \mathrm{ml}$ (Sigma-Aldrich) was employed for selecting $E$. coli transformants. Mating assays were performed on complete medium, consisting of $5 \mathrm{~g}$ of casamino acids, $1.5 \mathrm{~g}$ of ammonium nitrate, and $10 \mathrm{~g}$ of yeast extract per liter of $\mathrm{H}_{2} \mathrm{O} ; 62.5 \mathrm{ml}$ of $U$. maydis salt solution $\left(\mathrm{KH}_{2} \mathrm{PO}_{4}\right.$ at $16 \mathrm{~g} /$ liter, $\mathrm{Na}_{2} \mathrm{SO}_{4}$ at $4 \mathrm{~g} /$ liter, $\mathrm{KCl}$ at $8 \mathrm{~g} / \mathrm{liter}$, $\mathrm{MgSO}_{4} 7 \cdot 7 \mathrm{H}_{2} \mathrm{O}$ at $2 \mathrm{~g} /$ liter, and $\mathrm{CaCl}_{2} \cdot 2 \mathrm{H}_{2} \mathrm{O}$ at $1 \mathrm{~g} /$ liter, $\mathrm{pH} 7$ ); and $8 \mathrm{ml}$ of trace elements $\left(\mathrm{H}_{3} \mathrm{BO}_{3}\right.$ at $60 \mathrm{mg} / \mathrm{liter}, \mathrm{MnCl}_{2} \cdot 4 \mathrm{H}_{2} \mathrm{O}$ at $140 \mathrm{mg} /$ liter, $\mathrm{ZnCl}_{2}$ at $400 \mathrm{mg} /$ liter, $\mathrm{Na}_{2} \mathrm{MoO}_{4} \cdot 2 \mathrm{H}_{2} \mathrm{O}$ at $40 \mathrm{mg} /$ liter, $\mathrm{FeCl}_{3} \cdot 6 \mathrm{H}_{2} \mathrm{O}$ at $100 \mathrm{mg} /$ liter, and $\mathrm{CuSO}_{4} \cdot 5 \mathrm{H}_{2} \mathrm{O}$ at $400 \mathrm{mg} /$ liter) (23) containing 1\% charcoal (Sigma-Aldrich) (22).

Nucleic acid procedures. The $\Delta s n f l$ mutant strains were generated by completely replacing the snfl open reading frame (ORF) with a carboxin-resistant gene cassette $(c b x)$. The $5^{\prime}$ flank region of snfl $(1 \mathrm{~kb})$ was amplified from genomic DNA with primers MN1: CTCACAAGCAAAGCAGCGT and MN2: CAGCGAACGGCGTTCTTCAATCCGTG, cloned into vector pCR 2.1-TOPO (Invitrogen, Carlsbad, CA), and then excised with EcoRI and introduced into the EcoRI site in pCBX5 (28) to generate $\mathrm{pCBX} 55$. The correct orientation of the $5^{\prime}$ flank was confirmed by digesting the resulting plasmid with SacI. The 3' flank (1 kb) was amplified with primers MN3: GGGCCC GAGCACCATTGAGCGTGAATGG and MN4: GGGCCCAT
GTTGGGCTGCTGCGAATGCG, TOPO-cloned, and then excised with ApaI. The resulting fragment was introduced into the ApaI site of pCBX55. Clones carrying the appropriately oriented $3^{\prime}$ flank were identified by HindIII digestion. The resulting plasmid was named pCBX553. Correct assembly of the deletion construct was further confirmed by sequencing. A linear DNA fragment containing $c b x$ flanked by $1 \mathrm{~kb}$ of the 5' and $3^{\prime}$ snfl ORF flanks was obtained by digesting pCBX553 with SacI and $K p n I$. This fragment was gel purified and used to transform wildtype $U$. maydis strains $1 / 2$ (mating type $a l b 1$ ) and 2/9 (mating type $a 2 b 2$ ) protoplasts as previously described (43). Transformants were initially tested by polymerase chain reaction (PCR) with primers SNF1Fw: CTCGAATTGGTCGGTGAT and SNF1Rv: TACATCTTGCAGCAGACA for the absence of the snfl ORF, and with primers cbx3out: CATTTCTCGTGATTG TCC and snf13out: TTGCCAAACGTAGCGTTG for homologous integration of the $c b x$ resistance cassette within the snfl locus. Further confirmation was provided by Southern blot hybridization. Genomic DNA $(10 \mu \mathrm{g})$ from each strain was digested with $B g l \mathrm{II}$ and resolved on a $0.7 \%$ agarose gel stained with ethidium bromide. DNA was transferred overnight by capillarity to Hybond XL (Amersham Pharmacia Biotech, Piscataway, $\mathrm{NJ})$ nylon membrane in $10 \times \mathrm{SSC}(1 \times \mathrm{SSC}$ is $0.15 \mathrm{M} \mathrm{NaCl}$ plus $0.015 \mathrm{M}$ sodium citrate) and crosslinked by UV light. For the probe, $1 \mathrm{~kb}$ of the snfl $3^{\prime}$ flank was amplified and digoxigenin (DIG) labeled using Roche DIG-high Prime kit, and the Roche Wash and Block Buffer Set was used for hybridization steps (Roche, Indianapolis, IN). Probe labeling and hybridization procedures were performed according to the manufacturer's instructions. X-ray film (Kodak, Rochester, NY) was developed after 10 min of exposure.

Quantitative reverse-transcription PCR quantification of CWDE gene expression. Total RNA for quantitative reversetranscription (qRT)-PCR quantification of relative transcript accumulation was extracted using a Spectrum Plant Total RNA kit (Sigma-Aldrich). cDNA was synthesized using the SuperScript III First Strand Synthesis System for RT-PCR (Invitrogen) using oligo-dT as primer and according to the manufacturer's recommendations. Transcript abundance was quantified by qRT-PCR using SYBR-GREEN methodology (Bio-Rad, Hercules, CA) with gene-specific primers designed through the Integrated DNA Technologies website (http://www.idtdna.com/Home/Home.aspx). Reactions were performed on a Cepheid SmartCycler I (Cepheid, Sunnyvale, CA). CWDE gene transcript relative expression levels were calculated according to $\Delta$ cycle threshold calculations $\left(2^{-\Delta \Delta C T}\right.$ method) (31). Primer sequences are listed in Table 2. Relative gene expression was estimated by normalizing target transcript levels to the cyclophilin gene, cprl (um03726) (12). Means of gene expression fold increase and their corresponding standard error were calculated based on three biological replicates.

Functional complementation of yeast $\triangle S N F 1$. Yeast reference strain W303 (40) (leu2-3,112 trp1-1 can1-100 ura3-1 ade2-1 his3-11 15) (wiki.yeastgenome.org/index.php/CommunityW303.html) and the derived $\triangle S N F 1$ MCY4908 (leu23,112 trp1-1 can1-100 ura3-1 ade2-1 his3-11 15 $\Delta S N F 1$ ) strain (21) were maintained in yeast extract peptone dextrose (YPD) medium ( $1 \%$ yeast extract, $2 \%$ bacto-peptone, and $2 \%$ glucose).

TABLE 1. Ustilago maydis strains used in this study

\begin{tabular}{|c|c|c|}
\hline Strain & Relevant genotype & Source \\
\hline $1 / 2$ & albl (also known as strain 521) & Gold et al. 1997 \\
\hline $2 / 9$ & $a 2 b 2($ near isogenic to $1 / 2)$ & Gold et al. 1997 \\
\hline $18 / 9$ & $a 1 b 1 \Delta s n f 1:: c b x$ & This study \\
\hline $18 / 10$ & $a l b 1 \Delta s n f 1:: c b x$ & This study \\
\hline $18 / 11$ & $a 2 b 2 \Delta s n f 1:: c b x$ & This study \\
\hline $18 / 12$ & $a 2 b 2 \Delta s n f 1:: c b x$ & This study \\
\hline ect7 & $a l b 1$ ectopic snfl::cbx & This study \\
\hline
\end{tabular}


The $U$. maydis snfl and the $S$. cerevisiae $S N F 1$ ORFs were amplified from corresponding genomic DNA and directionally cloned into the URA3 containing plasmid pWS28 (30) carrying the constitutively expressed $P G X$ promoter at the EcoRI and NotI sites to generate plasmid pWS28SNF1 and pWS28UMsnf1, respectively. Yeast strain MCY4908 was transformed with either empty vector pWS28, pWS28SNF1 or pWS28snf1 according to a standard yeast transformation protocol (14). Transformants were first selected on synthetic dextrose minus uracil (SD-URA) medium, and then tested on YEPS amended with antimycin at $1 \mu \mathrm{g} / \mathrm{ml}$ (Sigma-Aldrich) to block respiration.

$U$. maydis mating and pathogenicity analysis. Mating plate assays were used to assess mutant mating abilities. Indicated strains were grown overnight in PDB and equal volumes of each of the mating strains were co-spotted on charcoal mating plates, sealed with parafilm, and incubated at room temperature in the dark for $24 \mathrm{~h}$. White dikaryotic filaments indicated a successful mating reaction.

For pathogenicity tests, 7-day-old 'Golden Bantam' maize seedlings were co-inoculated with strain mixtures of $10^{6}$ cells $/ \mathrm{ml}$. Plants were kept in a growth chamber with cycles of $16 \mathrm{~h}$ of day at $28^{\circ} \mathrm{C}$ and $8 \mathrm{~h}$ of night at $20^{\circ} \mathrm{C}$. Symptom development was scored 7, 10, and 14 days postinoculation (dpi) and each plant individually assigned a disease rating based on the following disease scale (18) $0=$ no symptoms, $1=$ anthocyanin production or chlorosis, $2=$ small leaf galls, $3=$ small stem galls, $4=$ large stem galls, and 5 = plant death. Disease index was calculated as the average disease rating $[(\Sigma$ disease rating for each plant $) /$ total number of plants]. For each mutant strain considered, three independent biological replicates of pathogenicity tests were conducted. Severity rating of each pathogenicity test was analyzed by using a marginal effects nonparametric analysis based on ranks, as described in Shah and Madden (36).

\section{RESULTS}

Identification and deletion of the $U$. maydis $S N F 1$ ortholog. In order to investigate the potential role of the U. maydis SNF1 ortholog as a key regulator of glucose repression as well as CWDE expression in this fungus, we created $\Delta s n f l$ mutant strains by completely removing the gene ORF. The U. maydis SNF1 ortholog, snf1 (um11293), was identified based on S. cerevisiae Snf1 protein sequence similarity by searching the genome (http://mips.gsf.de/genre/proj/ustilago) using the protein BLASThomology search algorithm. The identified ortholog, snfl (e = $1.8 \mathrm{e}^{-140}$ ) encodes an 841-amino-acid peptide with a predicted molecular mass of $\approx 92 \mathrm{kDa}$. National Center for Biotechnology Information alignment software indicates that the predicted protein encoded by um11293 shares 58 and $51 \%$ identity with Snf1p orthologs from Cryptococcus neoformans and S. cerevisiae, respectively. The serine/threonine (Ser/Thr) kinase catalytic domain extends from residue 52 to 303 and exhibits a high similarity to the Snf1 Ser/Thr catalytic domain in other fungi (Fig. 1). A well-conserved residue among Snf1p-related proteins is threonine 210 in the activation loop of the catalytic domain. Phosphorylation at this threonine by upstream kinases is indis- pensable for activation of the catalytic kinase domain (29). In $U$. maydis Snf1, this threonine (Thr 207) and the sequence context in which it is located have been conserved. Gene replacement by homologous recombination at the snfl locus was initially tested in transformants by PCR and further confirmed by Southern blot (Fig. 2). No obvious morphological phenotype differences were observed under the light microscope between $\Delta s n f l$ and wild-type strains grown in liquid PDB.

$U$. maydis snf1 is sufficient to complement a $S$. cerevisiae $\triangle S N F 1$ phenotype. In $U$. maydis, the $s n f 1$ gene and the protein it encodes have not previously been characterized. As a way to initially describe the $U$. maydis snfl gene function, we tested whether this gene is capable of rescuing the phenotype of a $S$. cerevisiae $\triangle S N F 1$ mutant strain. In $S$. cerevisiae, Snf1 kinase is essential for releasing the transcriptional repression imposed on the $S U C 2$ gene by glucose when this sugar is depleted from the medium. SUC2 encodes a secreted invertase responsible for hydrolyzing sucrose into glucose and fructose, allowing the cells to ferment these sugars (5). Consequently, deletion of SNF1 abolishes the ability of the yeast cells to grow by fermentation on medium containing sucrose as the sole carbon source. Because the $U$. maydis snfl gene contains no introns, the complete ORF was cloned into yeast expression vector pWS28 to generate pWS28snfl. As a positive control, the $S$. cerevisiae SNF1 ORF was cloned into pWS28 and the resulting plasmid named pWS28SNF1. Yeast transformants carrying these plasmids were initially selected on SD-URA medium for the presence of plasmid (see Materials and Methods) and then transferred to medium containing sucrose as the carbon source (yeast extract peptone sucrose [YPS] medium) to test their ability to grow on sucrose (Fig. 3). YPS plates were amended with antimycin A $(1 \mu \mathrm{g} / \mathrm{ml})$ to block respiration and any possible growth not due to fermentation. Only those strains carrying either pSW28snf1 or pSW28SNF1 grew on the YPS medium, showing that $U$. maydis snfl can functionally complement the $S$. cerevisiae $S N F 1$ mutation.

CWDE expression. The genome of $U$. maydis contains 33 potential hydrolytic enzymes able to work on living or dead plant tissues (26). Deletion of snfl orthologs in other plant-pathogenic fungi was shown to drastically reduce or completely abolish the expression of several CWDE genes. Based on the information concerning other plant-pathogenic fungi, we chose to test the expression patterns of several $U$. maydis CWDE orthologs for which the snf1 serine threonine kinase is required to release the gene transcriptional repression imposed by glucose $(32,41)$. A first attempt to score expression of several CWDE genes encoding xylanases (um06350 and um03411), glucanases (um04368, um00235), pectin methyltransferase (um03516), $\alpha$-L-arabinofuranosidase (um04309), and polygalacturonase (um02510) in media containing either glucose or an alternative carbon source was carried out by Northern blots. The $\Delta s n f 1$ strain 18/9 and wildtype strain $1 / 2$ were grown overnight in PDB, washed twice with sterile water, and then plated on MM amended with one of the following carbon sources: glucose, xylan, or pectin. After 2 days of incubation at $28^{\circ} \mathrm{C}$, fungal cells were collected and total RNA extracted. Of the seven tested genes, we were only able to detect transcripts corresponding to the xylanase gene um03411. For this

TABLE 2. Ustilago maydis cell wall degrading enzyme genes tested by quantitative reverse-transcription polymerase chain reaction

\begin{tabular}{llll}
\hline Gene $^{z}$ & \multicolumn{1}{c}{ Enzyme } & \multicolumn{1}{c}{ Forward primer } \\
\hline um04422 & Endo- $\beta-1,4-x y l a n a s e$ & GACCATCACCGATTTCGTCACCA & Reverse primer \\
um04897 & Endo- $\beta-1,4$-xylanase & AGAAGAATGTGCGTCCAGAGGGTT & TGATGCATGTCTTCTTGAAGCCGT \\
um06350 & Endo- $\beta-1,4$-xylanase & AGTTTGCCACTGTCCTTGCTTTCG & TGGCAGCGTTACCGTTGTAGTTCT \\
um03411 & Endo- $\beta-1,4$-xylanase & AAAGCTGATCCGAGGTCATACGCT & ACCTTGCCCTTGTATCTTCCCACA \\
um02510 & PGU1 - endo-polygalacturonase & CCAACGTTCGCAACCAAGATGACT & ACACTACCAATCGACAAGCCGTGA \\
um02523 & Endoglucanase 1 precursor & GCCTGGTTGCAAGTGGAGAATGAA & TGACAACCAGTTCGGTCGATGTGA \\
um03726 & Cyclophilin (reference) & ACGCCGATTCACTTCGTC & AACGACGATCCCTCGTAACCGAA \\
\hline
\end{tabular}

${ }^{\mathrm{z}}$ Ustilago maydis gene annotation: http://mips.helmholtz-muenchen.de/genre/proj/ustilago/. 
gene, no transcript accumulation was detected when wild-type or $\Delta$ snfl strains were grown on glucose. However, after cells were shifted to MM-xylan, transcript was detected at comparable levels in both the wild-type $1 / 2$ and $\Delta s n f 1$ 18/9 strains. These results sug- gested that the expression of um03411 encoding a potential xylanase is subject to glucose repression but, contrary to the initial hypothesis, snfl appears to be dispensable for releasing the transcriptional repression of this gene imposed by glucose (data not shown).

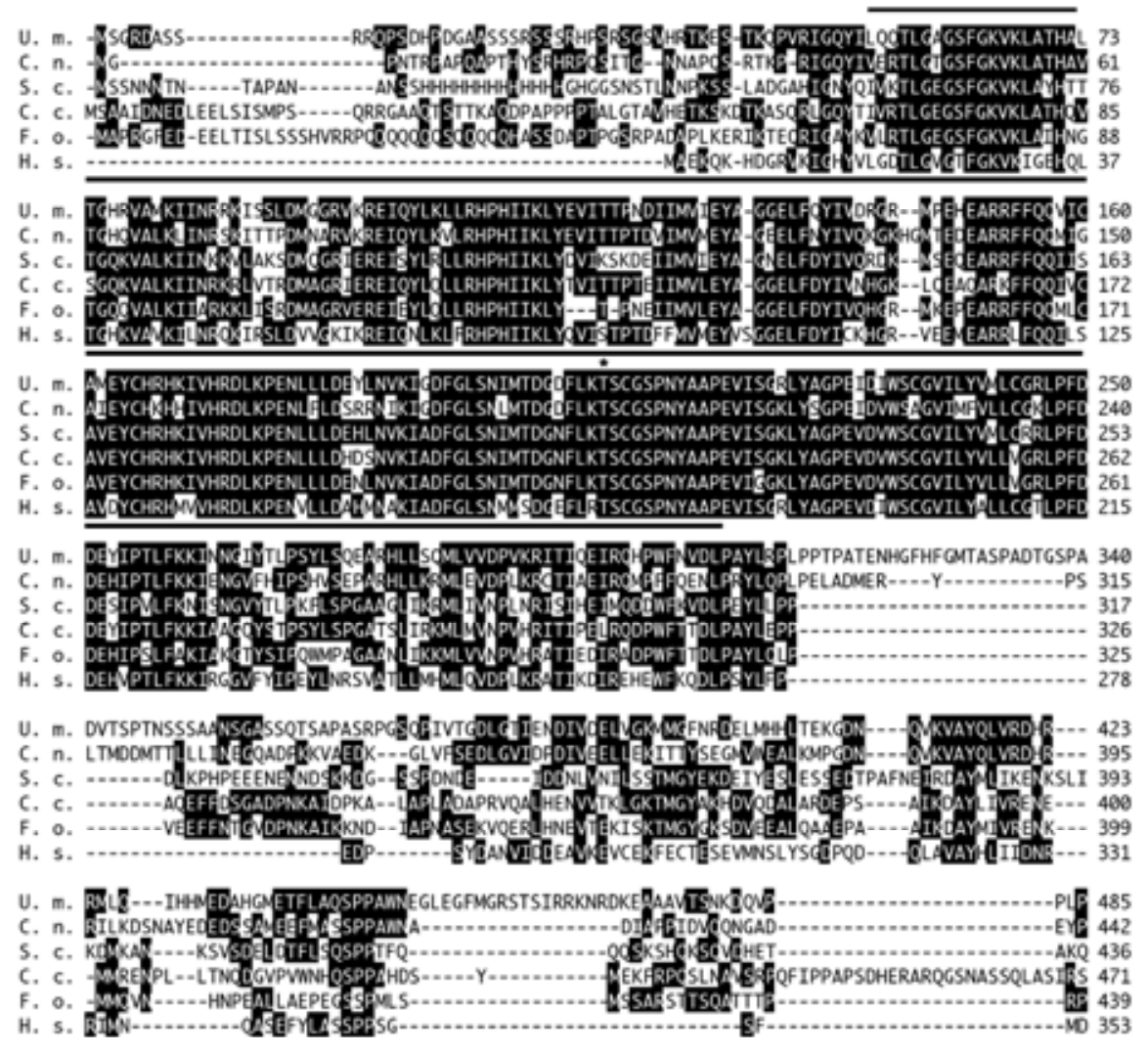

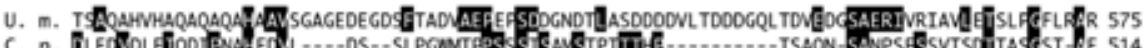

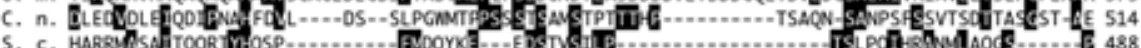

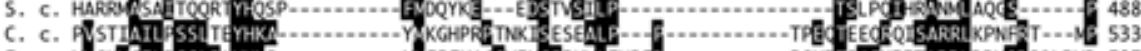

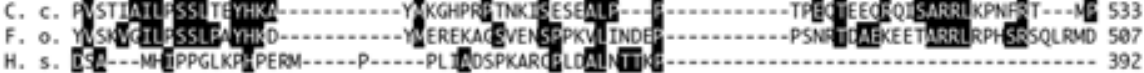

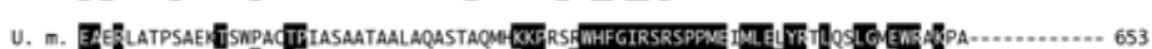

.

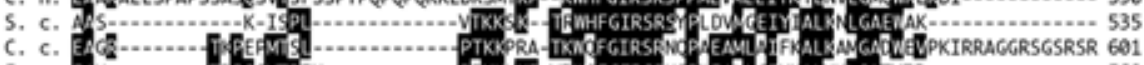
F. O. EN N-.....- DR d

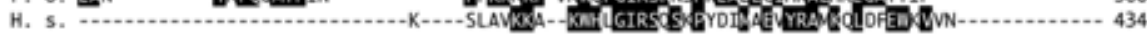

U. m. -...-......-AKQ 674

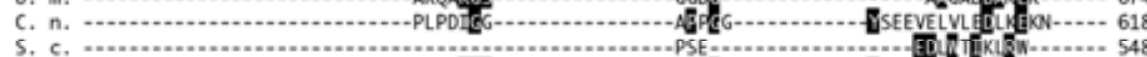

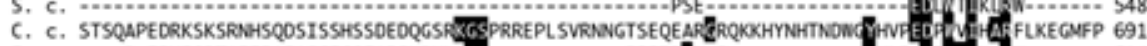

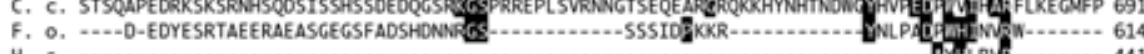

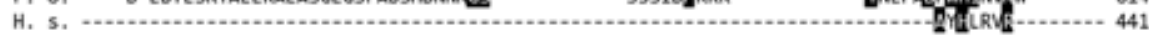

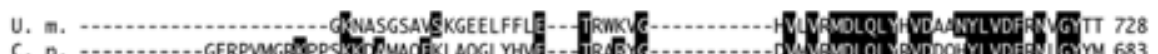

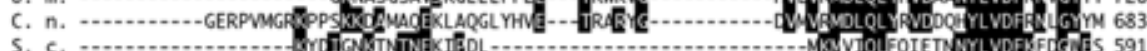

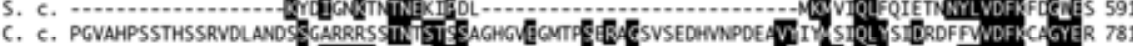

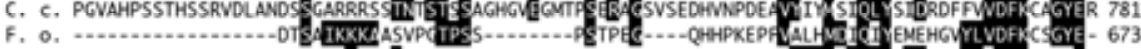

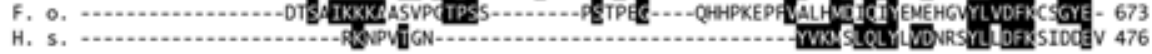

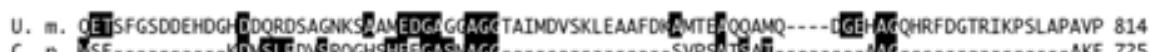

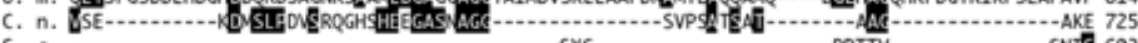

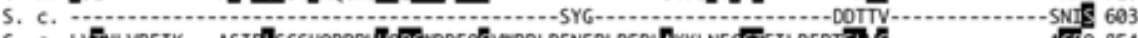

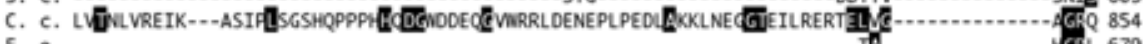

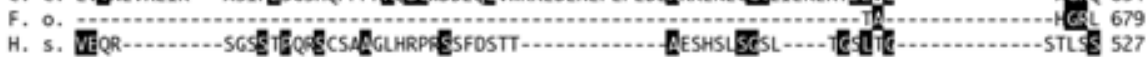

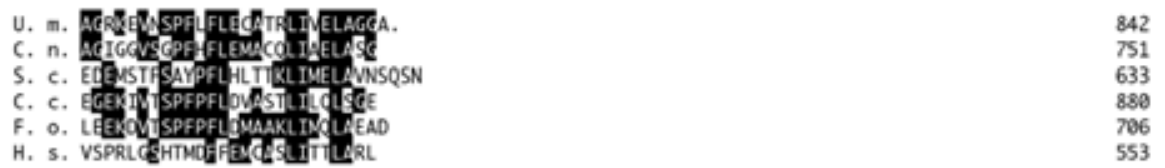

Fig. 1. Alignment showing homology among different Snf1 orthologs. Snf1 orthologs are shown in the following order from top to bottom: Ustilago maydis, Cryptococcus neoformans, Saccharomyces cerevisiae, Cochliobolus carbonum, Fusarium oxysporum, and Homo sapiens. Black bars above the sequence indicate the serine/threonine kinase domain. The asterisk indicates the conserved threonine 210 of $S$. cerevisiae Snf1 critical for activation by upstream kinases. Conserved amino acids shown in black. Amino acid position within the protein is indicated to the right. 
Because some of the CWDE genes might be expressed at levels difficult to detect by Northern blot, we sought to quantify the relative expression in wild-type and $\Delta s n f 1$ 18/9 strains using the more sensitive method of qRT-PCR. We initially included in our analysis all the genes tested by Northern blots as well as some additional genes encoding other potential CWDE enzymes. In agreement with our previous Northern results, for many of the tested CWDE genes, no transcripts were detected. Therefore, we decided to conduct our quantification analysis with those genes for which transcripts were detected (Table 2). For each strain, 200-ml PDB cultures were grown overnight to an optical density of $\approx 0.5$, washed, divided, and shifted to MM containing $1 \%$ of either glucose (MM-G), xylan (MM-X), pectin (MM-P), glucose plus xylan (MM-GX), or glucose plus pectin (MM-GP).

After $24 \mathrm{~h}$, RNA was extracted from the cells and cDNA was synthesized. No changes in um03411 or um06350 relative tran- script levels were observed when cells were shifted from MM-G to MM-GX. Similar results were obtained for genes um02510 and um02523 when cells were transferred from MM-G to MM-GP (data not shown). These results indicated that presence of the enzyme's principal substrate is not sufficient to induce the corresponding gene. We then compared the fold change in relative transcript levels of each gene when cells were shifted from MM-G to either MM-X or MM-P. The qRT-PCR results reinforce the hypothesis that expression of xylanases um03411 and um06350, pectinase um02510, and endoglucanase um02523 are strongly repressed by glucose, because their transcript accumulations were dramatically higher in the nonrepressive conditions in both strains than in glucose (Fig. 4). However, the relative expression of polygalacturonase gene um02510 and endoglucanase um02523 in MM-P was lower in the mutant 18/9 than in the wild-type strain $1 / 2$, indicating that snfl is required for full

A
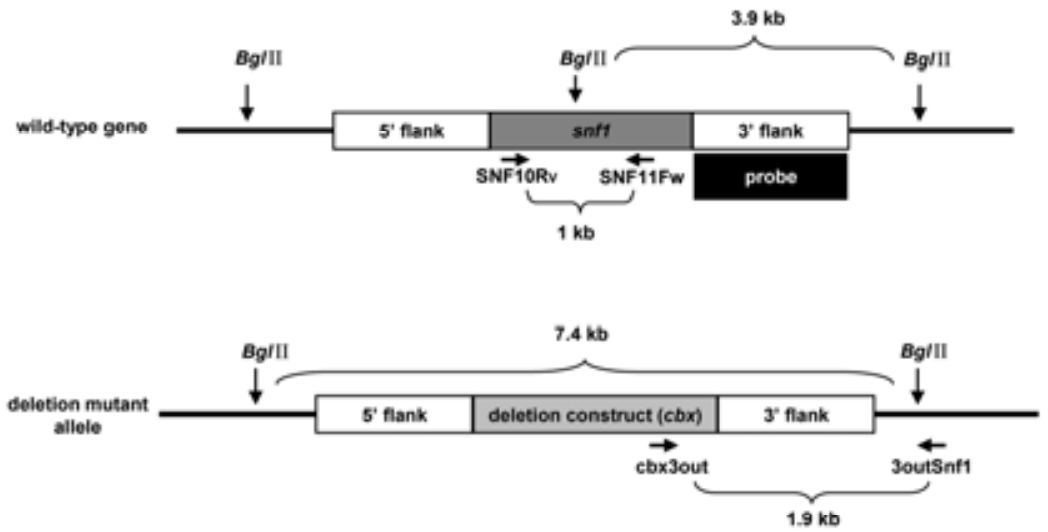

B
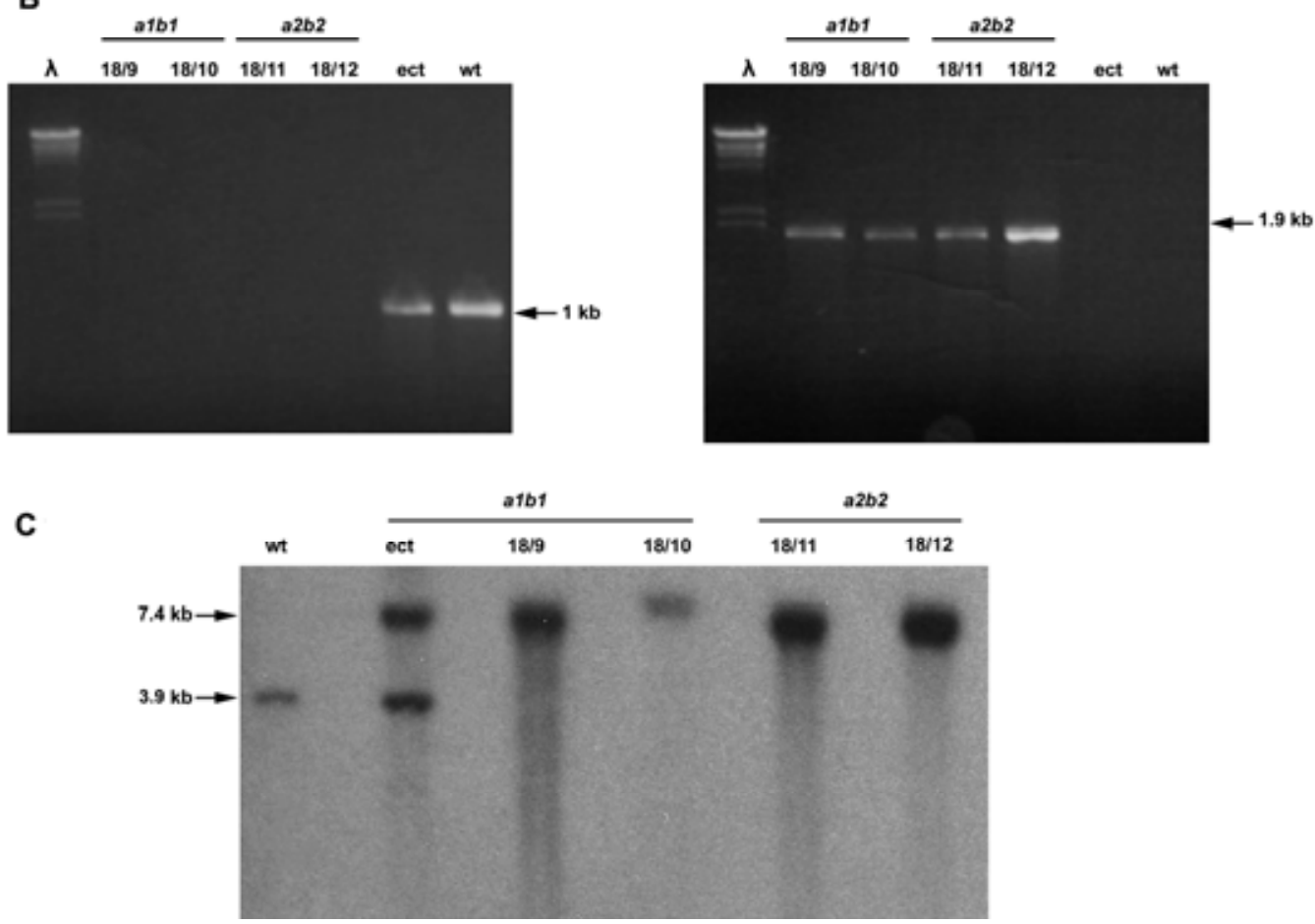

Fig. 2. Deletion of snf1 in Ustilago maydis. A, Schematic representation of the wild type and the mutant allele generated by gene replacement. Horizontal arrows indicate the positions of polymerase chain reaction (PCR) primers used to screen transformants. Size of the expected PCR products is indicated below the primer sets. The Southern blot probe and position of the recognition sites of restriction enzymes used to digest fungal genomic DNA are indicated. Lengths of Southern blot hybridizing bands are indicated above the figure. B, Transformants of both mating types, $a 1 b 1$ and $a 2 b 2$, were initially screened for snf 1 gene replacement by PCR. Primers: SNF10FW and SNF11RV were used to screen for the absence of the snf1 open reading frame. Primers cbx3out and 3outSnf1 were used to screen for homologous integration of the carboxin $(c b x)$ deletion construct. Length of PCR products is indicated to the right of images (arrows). C, Gene deletion was confirmed by Southern blot hybridization. Genomic DNA from wild-type and snfl transformants were digested with BglII. The size of hybridizing bands is indicated in kilobases to the left (arrows). Strains are indicated above; wt $=$ wild type, ect $=$ ectopic, $18 / 9=a 1 b 1 \Delta s n f 1:: c b x, 18 / 10=a 1 b 1 \Delta s n f 1:: c b x, 18 / 11=$ $a 2 b 2 \Delta s n f 1:: c b x, 18 / 12=a 2 b 2 \Delta s n f 1:: c b x$. Mating type of transformants, $a 1 b 1$ or $a 2 b 2$, is indicated above (bars). 
induction of these genes. On the other hand, in opposition to our prediction, the induction of xylanase genes um03411 and um06350 was 2.5 and 1.7 times higher, respectively, in the mutant $18 / 9$ than in the wild-type $1 / 2$ strain, indicating that the absence of snfl may marginally increase transcript accumulation of these two genes.

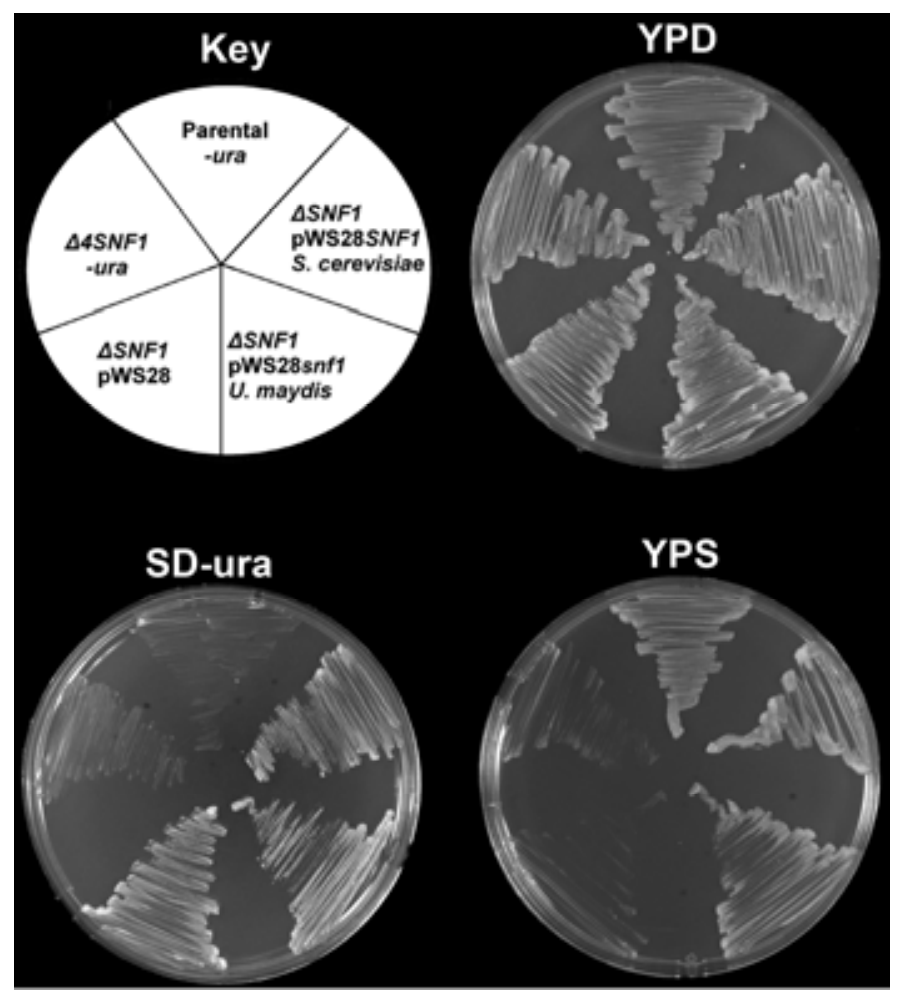

Fig. 3. Complementation of the $\triangle S N F 1$ Saccharomyces cerevisiae strain with the Ustilago maydis snf1 gene. Yeast parental-ura (W303: leu2-3,112 trp1-1 can1-100 ura3-1 ade2-1 his3-11 15) and derived $\triangle S N F 1-u r a$ (MCY4908: leu2-3,112 trp1-1 can1-100 ura3-1 ade2-1 his3-11 15 SSNF1) S. cerevisiae strains were transformed with either empty vector pWS28, pWS28snfl (pWS28 carrying $U$. maydis snf1 open reading frame [ORF]), or pWS28SNF1 (pWS28 carrying S. cerevisiae SNF1 ORF). Transformants were scored for their ability to grow on medium containing sucrose as the sole carbon source. Strains were plated as indicated in the key; yeast extract peptone dextrose (YPD) medium, synthetic defined-ura (glucose medium lacking uracil), and yeast extract peptone sucrose (YPS) medium amended with antimycin $(1 \mu \mathrm{l} / \mathrm{ml})$.
Carbon source utilization. In $S$. cerevisiae, $S N F 1$ is indispensable for growth on alternative carbon sources (other than glucose) and $\triangle S N F 1$ mutants are unable to utilize sucrose or other nonfermentable sugars. Similarly, the SNF1 homolog of Cochliobolus carbonum and $F$. oxysporum are required for proper absorption or utilization of simple and complex carbon sources other than glucose $(32,41)$. Based on this knowledge, we decided to test the growth efficiency of our $\Delta s n f 1$ strains on different carbon sources to observe if the same held true for $U$. maydis. Two independent $\Delta s n f 1$ mutants (18/9 and 18/10), the wild-type $1 / 2$, and one ectopic integrant strain (ect7) were grown overnight in PDB and a serial dilution of each culture was spotted onto solid MM amended with either glucose, sucrose, galactose, xylan, or pectin or, alternatively, onto PDA. For each strain, the growth on a particular alternative carbon source was compared with the corresponding strain growth on MM containing solely glucose (Fig. 5). According to our results, the $\Delta s n f l$ mutation does not seem to impair $U$. maydis's ability to grow on the alternative carbon sources tested. On any of the carbon sources, the $\Delta s n f l$ strains $18 / 9$ and 18/10 can sustain growth similar to the wild-type or ectopic strains. Therefore, contrary to the case of $S$. cerevisiae, $F$. oxysporum, and $C$. carbonum, in the basidiomycete $U$. maydis the snfl gene appears dispensable for the utilization of alternative sugars.

Deletion of the $U$. maydis snf1 gene slightly reduces virulence. $U$. maydis is a plant-pathogenic fungus and much of its life cycle must occur within its maize host plant. Therefore, the ability of $U$. maydis to sustain a pathogenic life style is crucial for the survival of the species. In order to test the pathogenic potential of $\Delta s n f l$ strains, we co-inoculated 7-day-old maize seedlings with pairwise combinations of compatible wild-type or $\Delta s n f 1$ strains and monitored disease progression based on severity of symptoms. The pathogenicity test corresponding to three independent biological replicates conducted with mutant strains 18/9 (a1b1) and 18/11 (a2b2) is summarized in Table 3. When plants were co-inoculated with compatible $4 s n f l$ strains (treatment 4), the average disease index at either 7,10 , or $14 \mathrm{dpi}$ was lower than when they were infected with any other strain combinations. However, dikaryons formed by compatible $\Delta s n f 1$ strains induced all the typical disease symptoms (chlorosis, anthocyanin production, and gall formation) observed in wildtype infections. Similar results were obtained when independent Asnfl strains $18 / 10$ and $18 / 12$ were used to inoculate plants. These results indicate that, in $U$. maydis, snfl is a relatively minor virulence determinant.
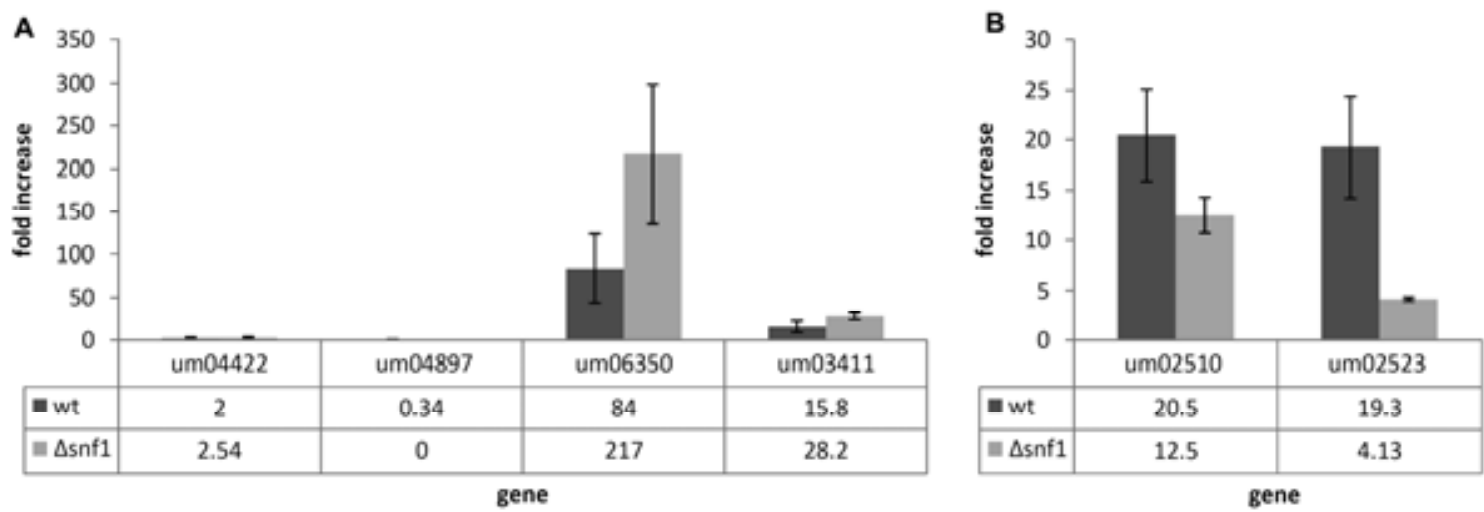

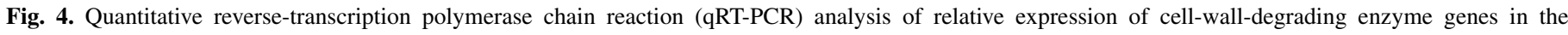

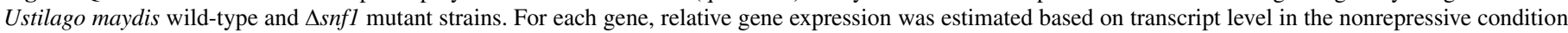

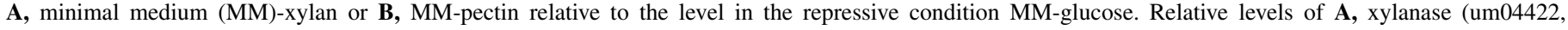

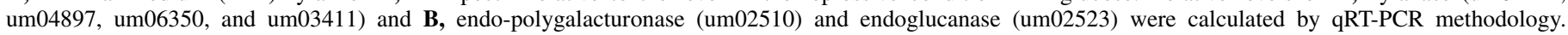

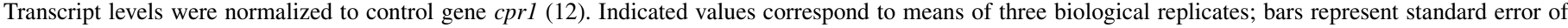

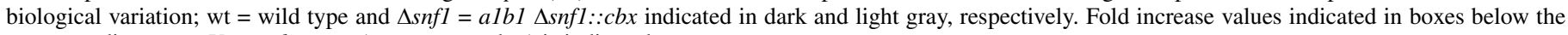
corresponding gene. U. maydis gene (um gene number) is indicated. 


\section{DISCUSSION}

The capacity of an organism to grow on a particular carbon source depends primarily upon the utilization of the appropriate enzyme set. Species that grow on a wide variety of carbon sources are able to do so because their genomes are equipped with the necessary genes encoding the enzymes that process each individual type of molecule. Nonetheless, it would be unnecessary and certainly wasteful to constitutively produce all those enzymes when the corresponding substrates are not available. Fortunately, cells have evolved strategies to avoid the energetically detrimental effect that such behavior would produce.

A common strategy among organisms is to adapt to their surroundings; that implies producing the required enzymes only when a particular carbon source becomes available. When multiple carbon sources are available, a particular carbon source is usually preferred over others. This is exemplified in S. cerevisiae, where glucose is the preferred carbon source and the production of enzymes involved in the degradation of other carbon sources is repressed at the transcriptional level when this sugar is accessible. This phenomenon, known as "catabolite" or "glucose repression" has been extensively studied in this yeast where the SNF1 gene, encoding a catalytic subunit of a protein-serine/threonine kinase $(5,6)$, is a central regulator $(4,16,20)$. The $S$. cerevisiae $S N F 1$ gene is required for the cell to utilize alternative carbon sources when glucose becomes limiting (5).

In many plant-pathogenic fungi, the enzymes involved in the depolymerization of the plant cell wall constituents (CWDE) are under glucose repression $(2,8)$. Deletion of $S N F 1$ orthologs in $C$. carbonum and $F$. oxysporum impaired the ability of these fungi to release glucose repression of CWDE genes, affecting their virulence as well $(32,41)$. In this work, we explored the potential
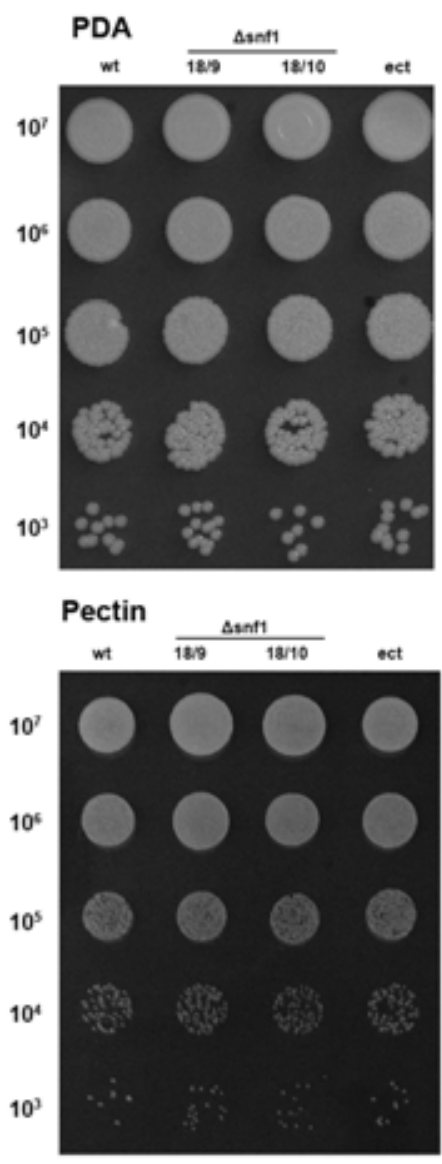
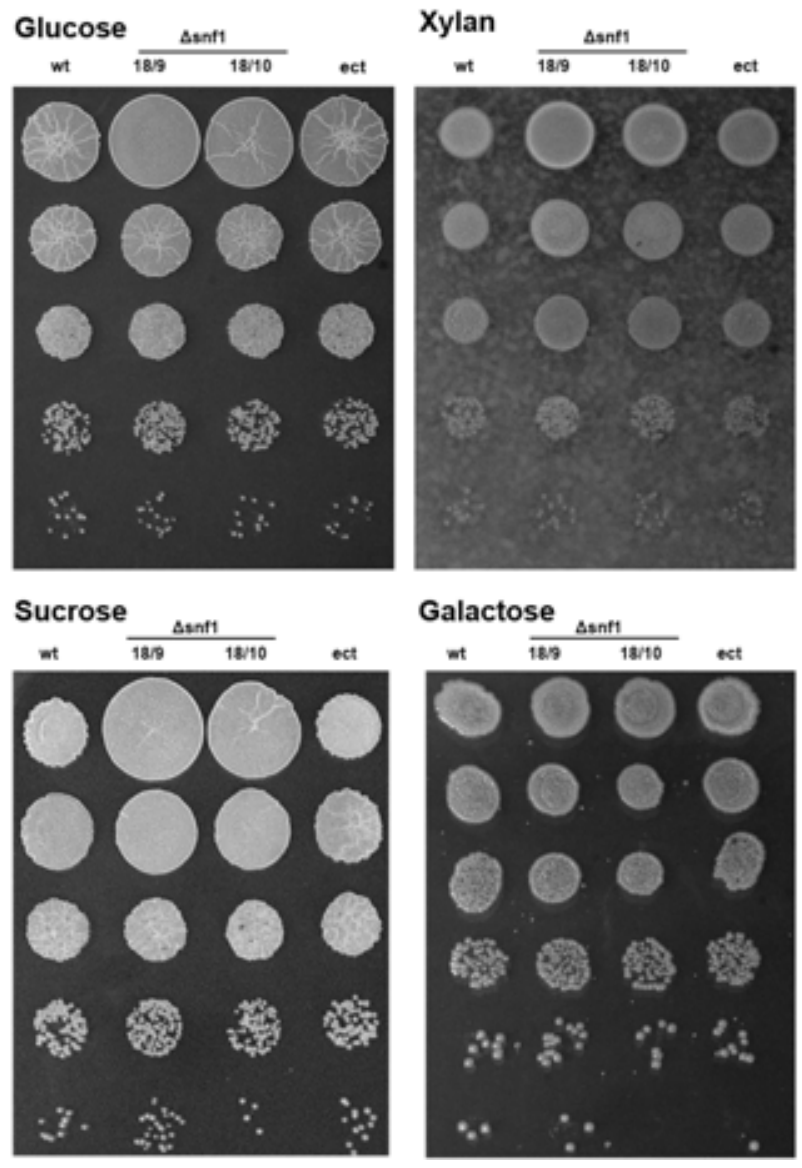

Fig. 5. Comparative growth of Ustilago maydis wild-type and $\Delta s n f 1$ mutant strains on various carbon sources. Serial 10 -fold dilutions of indicated strain cultures were plated on potato dextrose agar and minimal medium containing indicated carbon sources and incubated at $28^{\circ} \mathrm{C}$ for 3 days. Dilution series indicated to the left. Strains are indicated above; $\mathrm{wt}=$ wild type, ect = ectopic, $18 / 9=a 1 b 1 \Delta \operatorname{sif} 1:: c b x$, and 18/10 =alb1 $\Delta$ snfl::cbx. The $\Delta$ snfl strains are indicated (bars).

TABLE 3. Effect of $\Delta s n f 1$ on $U$. maydis pathogenicity

\begin{tabular}{|c|c|c|c|c|c|}
\hline \multirow[b]{2}{*}{ Treatment $^{\mathrm{y}}$} & \multirow[b]{2}{*}{ Dikaryon } & \multirow[b]{2}{*}{ No. of plants } & \multicolumn{3}{|c|}{ Disease index ${ }^{\mathrm{Z}}$} \\
\hline & & & $7 \mathrm{dpi}$ & $10 \mathrm{dpi}$ & $14 \mathrm{dpi}$ \\
\hline 1 & $+/+$ & $3 \times 20$ & $2.7 \pm 0.04$ (a) & $2.9 \pm 0.23$ (a) & $3.52 \pm 0.4$ (a) \\
\hline 2 & $+1-$ & $3 \times 20$ & $1.9 \pm 0.12$ (b) & $2.3 \pm 0.08(\mathrm{ab})$ & $3.15 \pm 0.1$ (a) \\
\hline 4 & $-1-$ & $3 \times 20$ & $1.6 \pm 0.05(b)$ & $1.9 \pm 0.10(\mathrm{~b})$ & $2.56 \pm 0.1$ (b) \\
\hline
\end{tabular}

y Treatment: paired strains are as follows $1=(1 / 2 \times 2 / 9), 2=(1 / 2 \times 18 / 11), 3=(18 / 9 \times 2 / 9)$, and $4=(18 / 9 \times 18 / 11)$. Inoculation was of $10^{6}$ cells $/ \mathrm{ml}$ for all strains.

${ }^{\mathrm{z}}$ Mean \pm standard error were calculated for each treatment based on three independent biological replicates. Disease scale $(18) 0=$ no symptoms, $1=$ anthocyanin production and/or chlorosis, $2=$ small leaf galls, $3=$ small stem galls, $4=$ large stem galls, and $5=$ plant death; dpi $=$ days postinoculation. Disease index is calculated as the average disease rating [ $(\Sigma$ disease rating for each plant $) /$ total number of plants]. Statistical analysis was performed using a nonparametric test of ordinal data in designed factorial experiments. Treatments with different letters at specific time points indicate a statistically significant difference at the $95 \%$ confidence interval. 
functions of the $U$. maydis $S N F 1$ ortholog, snfl, as a determinant of CWDE expression and virulence in this fungus.

The U. maydis snf1 gene um11293 was identified as the homo$\log$ of the SNF1 $\alpha$-catalytic subunit based on protein sequence similarity. Further examination of the $U$. maydis genome also indicated the presence of a homolog of the activating $\gamma$-subunit, Snf4p (um01350). Additionally, the $U$. maydis genome contains a single $\beta$-scaffolding subunit gene (um0668) instead of three paralogs as in $S$. cerevisiae. The fact that $U$. maydis snfl can functionally complement the phenotype of a yeast $\triangle S N F 1$ mutant strain serves as strong evidence that this gene is, indeed, an SNF1 ortholog. Therefore, $U$. maydis seems to conserve all the genetic elements that make up the SNF1 complex involved in the regulation of glucose repression.

With the notion that the identified $\operatorname{snfl}$ gene can function as a SNF1 ortholog, we then sought to investigate whether the gene was also involved in glucose repression of CWDE genes in $U$. maydis. We compared the expression patterns of several potential CWDE genes by Northern blot analysis but only detected transcripts corresponding to one of six CWDE genes tested. Because we failed to detect most of the CWDE transcripts by Northern blot, we used qRT-PCR, a more sensitive approach to evaluate gene expression. Our results revealed two different patterns depending on the nature of the CWDE tested. We first expanded our analysis of xylan-degrading enzyme genes by analyzing the expression of the four potential xylanase genes present in the $U$. maydis genome. Expression of xylanases um04422 and um04897 was independent of glucose availability, indicating that they are not under glucose repression. On the other hand, for xylanases um06350 and um03411, transcripts increased, on average, 85and 16-fold, respectively, when wild-type cells were shifted to MM containing xylan as the sole carbon source (MM-X). The fact that no induction of these genes was observed when cells were moved from growth in repressive conditions (MM-G) to a growth medium in which both the repressor (glucose) and inducer (xylan) were simultaneously present (MM-GX) further reinforced the notion that the genes are, indeed, under glucose repression. Unexpectedly, and in accordance with the pattern revealed by the Northern results, the induction of um06350 and um03411 after the shift to MM-X was 2.5 and 1.8 times higher, respectively, in $\Delta$ snfl than in the wild-type cells. This result clearly argues against snfl acting as a "positive" regulator of um06350 and um03411 induction during growth in alternative carbon sources. Rather, it suggests that snfl somehow marginally negatively regulates these genes when glucose is depleted. This comes as a contradiction to the well-documented cases of $C$. carbonum and $F$. oxysporum where the corresponding $S$. cerevisiae $S N F 1$ ortho$\operatorname{logs}$ are required for the expression of CWDE in the absence of glucose $(32,41)$.

We also investigated the pattern of expression of two CWDEs involved in the degradation of other plant cell wall polymers. The fold increase of polygalacturonase um02510 and endoglucanase um02523 was 20 and 19, respectively, when wild-type cells were shifted to MM-P, pointing to transcriptional repression by glucose of these genes. As with the xylanase genes, the presence of the inducer is not sufficient to induce um02510 and um02523 because no change in relative transcript levels for these genes was observed when cells were shifted from MM-G to MM-GP. On the other hand, the relative transcript accumulation of these genes in the $\Delta s n f 1$ cells after the switch to MM-P was much lower than in the wild-type strain, indicating that, in $U$. maydis, snfl is required for full derepression of um02510 and um02523.

Therefore, in U. maydis, snfl does not appear to be a universal element controlling glucose repression, although the expression of many CWDE genes are repressed by this sugar. In the case of xylanase genes, snfl appears to negatively regulate glucose repression whereas, in the case of the other CWDEs analyzed (um02510 and um02523), it acts as a positive regulator, much in the same way that has been described for $S N F 1$ orthologs in other systems. Regardless of its role in the regulation of CWDE gene expression, its deletion did not affect the capacity of the mutant strains to metabolize compounds other than glucose, indicating that $U$. maydis snfl is not critical for survival in the absence of glucose. This is in marked contrast to $S$. cerevisiae, C. carbonum, and $F$. oxysporum, where snfl deletion impairs the ability of these fungi to thrive on alternative carbon sources. However, our yeast complementation results clearly showed that $U$. maydis snfl was able to function as $S$. cerevisiae $S N F 1$, at least in regard to carbon source utilization. SNF1 has also been shown to be involved in the regulation of nitrogen metabolism, gluconeogenesis, and the glyoxylate and tricarboxylic acid cycles as well as respiration and $\beta$-oxidation $(19,27)$. It is very possible that $U$. maydis snfl regulates these processes in $U$. maydis. However, preliminary microarray data (data not shown) indicated that, in $U$. maydis, snfl is not required for derepression of glucose-repressed genes. Moreover, many of the genes that were induced in the absence of glucose exhibited a higher degree of induction in the $\Delta s n f l$ strain, reinforcing the notion that, in $U$. maydis, snfl may negatively regulate the expression of some genes. Further work is needed to accurately establish the full function of snfl in $U$. maydis.

$U$. maydis spends a great deal of its life living as a pathogen, prospering at the expense of its host, maize. It is only during this phase that sexual reproduction is possible in $U$. maydis and, therefore, pathogenic development is crucial for completing its life cycle. Because previous studies have demonstrated that snfl deletion affected virulence in other systems, we tested the capacity of $\Delta s n f l$ strains to cause disease in maize seedlings. Our pathogenicity results showed that disease caused by $\Delta$ snfl strains was slightly less severe than that caused by the wild type, suggesting that $U$. maydis snfl is required for full virulence.

In this work, we generated data showing that $U$. maydis does not strictly follow the $S$. cerevisiae, $C$. carbonum, and $F$. oxysporum snfl paradigm. Rather, we showed that it may act as either a positive or negative regulator of CWDE expression in relation to glucose repression. We also demonstrated that snfl is dispensable for $U$. maydis haploid growth on alternative carbon sources.

However, the $U$. maydis $\Delta s n f 1$ strains did exhibit a minor reduction in virulence. This suggests that, during pathogenic development, snfl is required for some processes associated with the ability of the fungus to cause disease. Additionally, snfl could positively regulate CWDE genes not included in our analysis which, together with those mentioned above, are important for degradation of cell wall polymers during pathogenic growth. Microarray data showed that um02523 along with two other endoglucanase genes and endopolygalacturonase um02510 are highly induced during $U$. maydis infection (13). Our data indicates that induction of these genes is severely reduced in $\Delta s n f 1$ cells, which may be one of the causes of the observed reduction in virulence.

\section{ACKNOWLEDGMENTS}

This work was supported by the United States Department of Agriculture National Research Initiative Competitive grant nos. 20013531910139 and 20033531913361 to S. E. Gold and a University of Georgia Dissertation Completion award to M. Nadal. We thank R. Christiano for assistance with statistical analyses and D. Andrews for critical review of the manuscript.

\section{LITERATURE CITED}

1. Ahuatzi, D., Riera, A., Pelaez, R., Herrero, P., and Moreno, F. 2007. Hxk2 regulates the phosphorylation state of Mig1 and therefore its nucleocytoplasmic distribution. J. Biol. Chem. 282:4485-4493.

2. Aro, N., Pakula, T., and Penttila, M. 2005. Transcriptional regulation of plant cell wall degradation by filamentous fungi. FEMS Microbiol. Rev. 
29:719-739.

3. Belien, T., Van Campenhout, S., Robben, J., and Volckaert, G. 2006. Microbial endoxylanases: Effective weapons to breach the plant cell-wall barrier or, rather, triggers of plant defense systems? Mol. Plant-Microbe Interact. 19:1072-1081.

4. Carlson, M. 1999. Glucose repression in yeast. Curr. Opin. Microbiol. 2:202-207.

5. Celenza, J. L., and Carlson, M. 1984. Cloning and genetic mapping of $S N F 1$, a gene required for expression of glucose-repressible genes in Saccharomyces cerevisiae. Mol. Cell. Biol. 4:49-53.

6. Celenza, J. L., and Carlson, M. 1986. A yeast gene that is essential for release from glucose repression encodes a protein kinase. Science 233:1175-1180.

7. Celenza, J. L., Eng, F. J., and Carlson, M. 1989. Molecular analysis of the SNF4 gene of Saccharomyces cerevisiae: Evidence for physical association of the SNF4 protein with the SNF1 protein kinase. Mol. Cell. Biol. 9:5045-5054.

8. Dean, R. A., and Timberlake, W. E. 1989. Production of cell walldegrading enzymes by Aspergillus nidulans: A model system for fungal pathogenesis of plants. Plant Cell 1:265-273.

9. Deising, H. B., Werner, S., and Wernitz, M. 2000. The role of fungal appressoria in plant infection. Microbes Infect. 2:1631-1641.

10. de Jong, J. C., McCormack, B. J., Smirnoff, N., and Talbot, N. J. 1997. Glycerol generates turgor in rice blast. Nature 389:244-245.

11. De Vit, M. J., Waddle, J. A., and Johnston, M. 1997. Regulated nuclear translocation of the Mig1 glucose repressor. Mol. Biol. Cell 8:1603-1618.

12. Doehlemann, G., van der Linde, K., Assmann, D., Schwammbach, D., Hof, A., Mohanty, A., Jackson, D., and Kahmann, R. 2009. Pep1, a secreted effector protein of Ustilago maydis, is required for successful invasion of plant cells. PLoS Pathog. 5:e1000290.

13. Doehlemann, G., Wahl, R., Vranes, M., de Vries, R. P., Kämper, J., and Kahmann, R. 2008. Establishment of compatibility in the Ustilago maydis/maize pathosystem. J. Plant Physiol. 165:29-40.

14. Elble, R. 1992. A simple and efficient procedure for transformation of yeasts. Biotechniques 13:18-20.

15. Emmett, R. W., and Parbery, D. G. 1975. Appressoria. Annu. Rev. Phytopathol. 13:147-165.

16. Gancedo, J. M. 1998. Yeast carbon catabolite repression. Microbiol. Mol. Biol. Rev. 62:334-361.

17. Garcia-Maceira, F. I., Di Pietro, A., and Roncero, M. I. 2000. Cloning and disruption of pgx4 encoding an in planta expressed exopolygalacturonase from Fusarium oxysporum. Mol. Plant-Microbe Interact. 13:359-365.

18. Gold, S. E., and Kronstad, J. W. 1994. Disruption of two genes for chitin synthase in the phytopathogenic fungus Ustilago maydis. Mol. Microbiol. 11:897-902.

19. Hardie, D. G., Carling, D., and Carlson, M. 1998. The AMP-activated/ SNF1 protein kinase subfamily: Metabolic sensors of the eukaryotic cell? Annu. Rev. Biochem. 67:821-855.

20. Hedbacker, K., and Carlson, M. 2008. SNF1/AMPK pathways in yeast. Front. Biosci. 13:2408-2420.

21. Hedbacker, K., Townley, R., and Carlson, M. 2004. Cyclic AMPdependent protein kinase regulates the subcellular localization of Snf1Sip1 protein kinase. Mol. Cell. Biol. 24:1836-1843.

22. Holliday, R. 1965. Induced mitotic crossing-over in relation to genetic replication in synchronously dividing cells of Ustilago maydis. Genet. Res. 10:104-120.

23. Holliday, R. 1974. Ustilago maydis. Pages 575-595 in: Handbook of Genetics. R. C. King, ed. Plenum Press, New York.

24. Jiang, R., and Carlson, M. 1997. The Snf1 protein kinase and its activating subunit, Snf4, interact with distinct domains of the Sip1/Sip2/Gal83 component in the kinase complex. Mol. Cell. Biol. 17:2099-2106

25. Juge, N. 2006. Plant protein inhibitors of cell wall degrading enzymes. Trends Plant Sci. 11:359-367.

26. Kamper, J., Kahmann, R., Bolker, M., Ma, L. J., Brefort, T., Saville, B. J., Banuett, F., Kronstad, J. W., Gold, S. E., Muller, O., Perlin, M. H., Wosten, H. A., de Vries, R., Ruiz-Herrera, J., Reynaga-Pena, C. G., Snetselaar, K., McCann, M., Perez-Martin, J., Feldbrugge, M., Basse, C. W., Steinberg, G., Ibeas, J. I., Holloman, W., Guzman, P., Farman, M., Stajich, J. E., Sentandreu, R., Gonzalez-Prieto, J. M., Kennell, J. C., Molina, L., Schirawski, J., Mendoza-Mendoza, A., Greilinger, D., Munch, K., Rossel, N., Scherer, M., Vranes, M., Ladendorf, O., Vincon, V., Fuchs, U., Sandrock, B., Meng, S., Ho, E. C., Cahill, M. J., Boyce, K. J., Klose,
J., Klosterman, S. J., Deelstra, H. J., Ortiz-Castellanos, L., Li, W., Sanchez-Alonso, P., Schreier, P. H., Hauser-Hahn, I., Vaupel, M., Koopmann, E., Friedrich, G., Voss, H., Schluter, T., Margolis, J., Platt, D., Swimmer, C., Gnirke, A., Chen, F., Vysotskaia, V., Mannhaupt, G., Guldener, U., Munsterkotter, M., Haase, D., Oesterheld, M., Mewes, H. W., Mauceli, E. W., DeCaprio, D., Wade, C. M., Butler, J., Young, S., Jaffe, D. B., Calvo, S., Nusbaum, C., Galagan, J., and Birren, B. W. 2006. Insights from the genome of the biotrophic fungal plant pathogen Ustilago maydis. Nature 444:97-101.

27. Kuchin, S., Vyas, V. K., and Carlson, M. 2002. Snf1 protein kinase and the repressors $\mathrm{Nrg} 1$ and $\mathrm{Nrg} 2$ regulate $\mathrm{FLO11}$, haploid invasive growth, and diploid pseudohyphal differentiation. Mol. Cell. Biol. 22:3994-4000.

28. Mayorga, M. E., and Gold, S. E. 2001. The $u b c 2$ gene of Ustilago maydis encodes a putative novel adaptor protein required for filamentous growth, pheromone response and virulence. Mol. Microbiol. 41:1365-1379.

29. McCartney, R. R., and Schmidt, M. C. 2001. Regulation of Snf1 kinase. Activation requires phosphorylation of threonine 210 by an upstream kinase as well as a distinct step mediated by the Snf4 subunit. J. Biol. Chem. 276:36460-36466.

30. Mokry, D. Z., Manandhar, S. P., Chicola, K. A., Santangelo, G. M., and Schmidt, W. K. 2009. Heterologous expression studies of Saccharomyces cerevisiae reveal two distinct trypanosomatid CaaX protease activities and identify their potential targets. Eukaryot. Cell 8:1891-1900.

31. Pfaffl, M. W. 2001. A new mathematical model for relative quantification in real-time RT-PCR. Nucleic Acids Res. 29:e45.

32. Ospina-Giraldo, M. D., Mullins, E., and Kang, S. 2003. Loss of function of the Fusarium oxysporum SNF1 gene reduces virulence on cabbage and Arabidopsis. Curr. Genet. 44:49-57.

33. Ruijter, G. J., and Visser, J. 1997. Carbon repression in Aspergilli. FEMS Microbiol. Lett. 151:103-114.

34. Schuller, H. J., and Entian, K. D. 1988. Molecular characterization of yeast regulatory gene CAT3 necessary for glucose derepression and nuclear localization of its product. Gene 67:247-257.

35. Scott-Craig, J. S., Panaccione, D. G., Cervone, F., and Walton, J. D. 1990. Endopolygalacturonase is not required for pathogenicity of Cochliobolus carbonum on maize. Plant Cell 2:1191-1200.

36. Shah, D. A., and Madden, L. V. 2004. Nonparametric analysis of ordinal data in designed factorial experiments. Phytopathology 94:33-43.

37. Smith, F. C., Davies, S. P., Wilson, W. A., Carling, D., and Hardie, D. G. 1999. The SNF1 kinase complex from Saccharomyces cerevisiae phosphorylates the transcriptional repressor protein Mig1p in vitro at four sites within or near regulatory domain 1. FEBS Lett. 453:219-223.

38. Snetselaar, K. M., and Mims, C. W. 1993. Infection of maize stigma by Usitlago maydis: Light and electron microscopy. Phytopathology 83:843850.

39. Snetselaar, K. M., and Mims, C. W. 1994. Light and electron microscopy of Ustilago maydis hyphae in maize. Mycol. Res. 98:347-355.

40. Thomas, B. J., and Rothstein, R. 1989. The genetic control of directrepeat recombination in Saccharomyces: The effect of rad52 and rad1 on mitotic recombination at GAL10, a transcriptionally regulated gene. Genetics 123:725-738.

41. Tonukari, N. J., Scott-Craig, J. S., and Walton, J. D. 2000. The Cochliobolus carbonum SNF1 gene is required for cell wall-degrading enzyme expression and virulence on maize. Plant Cell 12:237-248.

42. Treitel, M. A., Kuchin, S., and Carlson, M. 1998. Snf1 protein kinase regulates phosphorylation of the Mig1 repressor in Saccharomyces cerevisiae. Mol. Cell. Biol. 18:6273-6280.

43. Tsukuda, T., Carleton, S., Fotheringham, S., and Holloman, W. K. 1988. Isolation and characterization of an autonomously replicating sequence from Ustilago maydis. Mol. Cell. Biol. 8:3703-3709.

44. Vincent, O., and Carlson, M. 1999. Gal83 mediates the interaction of the Snf1 kinase complex with the transcription activator Sip4. EMBO J. 18:6672-6681

45. Walton, J. D. 1994. Deconstructing the cell wall. Plant Physiol. 104:11131118.

46. Wu, S. C., Ham, K. S., Darvill, A. G., and Albersheim, P. 1997. Deletion of two endo- $\beta$-1,4-xylanase genes reveals additional isozymes secreted by the rice blast fungus. Mol. Plant-Microbe Interact. 10:700-708.

47. Yang, X., Hubbard, E. J., and Carlson, M. 1992. A protein kinase substrate identified by the two-hybrid system. Science 257:680-682.

48. Yang, X., Jiang, R., and Carlson, M. 1994. A family of proteins containing a conserved domain that mediates interaction with the yeast SNF1 protein kinase complex. EMBO J. 13:5878-5886. 